\title{
ВИКОРИСТАННЯ ІДІОМ У СУЧАСНОМУ АНГЛІЙСЬКОМУ ДІЛОВОМУ ДИСКУРСІ
}

Досліджено проблему правильного використання таких лексичних засобів, як ідіоми в англійській діловій мові. Розглянуто теоретичні особливості поняття "ідіома" як стійкого неподільного лексичного засобу, який передає єдине поняття, зміст якого не визначається змістом складових його елементів. Проаналізовано комунікативні та експресивні функції ідіоматичних виразів та їх роль в оволодінні сучасною діловою англійською мовою студентами, рідною мовою яких не є англійська. Велику увагу приділено складнощам перекладу англійських ідіом через їх специфічні етнічні та культурні особливості. Наголошено на емоційному та експресивному ефектах фразеологічних одиниць під час ділових переговорів. Також зазначено, що багато англійських ідіом грунтуються на аналогіях та метафорах, і їх варто вивчати в контексті, щоб правильно зрозуміти їх значення. Показано, що, незважаючи на думку про те, що ділова мова суха, існує велика кількість англійських ідіом, які роблять ділову мову більш живою та виразнішою, і хоча у діловому світі є своя термінологія, багато ідіом часто використовують як у діловій мові, так і в небізнесовому середовищі, вони можуть бути ідеально використані у суспільному житті. Подано низку ідіом, які можуть бути використані у різних випадках: від дискусій та нарад до презентацій, переговорів, доповідей та листів тощо. Подано визначення до кожної фразеологічної одиниці, визначення супроводжуються прикладними реченнями, які ілюструють як значення, так і синтаксичні можливості ідіоми. Наведено приклади вживання ідіоматичних виразів відповідно до їх функціонального навантаження (започаткування бізнесу; мета та цілі; зосередження уваги; незгода та критика; кроки до компромісу та згоди) і це допомагає усвідомити, що відмінного знання ділової лексики та термінів недостатньо для того, щоб відчувати себе комфортно в робочих умовах, де спеціалізована англійська мова $\epsilon$ нормою. Набагато важливіше практичне оволодіння діловим спілкуванням у різних ситуаціях, вміння встановлювати більш особистий контакт між партнерами, створювати неформальну, доброзичливу атмосферу спілкування. Отже, знання ідіоматичних виразів та вміння правильно їх застосовувати надають студентам можливості, які допоможуть їм досягти рівня кваліфікації, необхідного для досягнення успіху у сучасному діловому світі.

Ключові слова: фразеологічні одиниці; ідіоматичні вирази; ділове спілкування; визначення; синтаксичні можливості; рівень кваліфікації.

\section{Вступ}

В епоху глобалізації та розвитку міжнародної співпраці, в епоху нових засобів комунікації, таких як електронна пошта, смартфони, мобільні телефони, знання особливостей бізнес-комунікацій, ділового лексикону $є$ надзвичайно важливим і необхідним для всіх, хто так чи інакше дотичний до міжнародної економіки, а саме експертів, менеджерів, маркетологів, економістів, юристів, перекладачів, директорів міжнародних компаній.

Однією з проблем, з якими стикаються фахівці, для яких англійська мова $є$ іноземною - це уникнення бути або надто офіційними, або надто неформальними та уникнення невідповідної форми мови (наприклад, використання мови вулиці під час важливої ділової зустрічі).

Актуальність цієї роботи визначається тим, що ідіоматична фразеологія є однією з найменш досліджених сфер ділового спілкування, оскільки переклад ідіом і використання їх у мові бізнесу - складний і комплексний процес і не є достатньо дослідженим у вітчизняному перекладознавстві.
Об'єктом дослідження є використання ідіоматичних виразів у діловій англійській мові.

Предметом дослідження є методи і засоби правильного використання ідіоматичних виразів, які можна сміливо використовувати практично з будь-якого приводу: від дискусій та зустрічей до презентацій, переговорів, доповідей та листів тощо.

Мета дослідження полягає у висвітленні комунікативних, експресивних функцій бізнес-ідіом та аналізі особливостей їх використання у діловій англійській мові, що дасть змогу застосувати їх як практичний матеріал для розвитку комунікативної компетенції студентів на заняттях з дисципліни "Ділова англійська мова".

Для досягнення мети потрібно виконати такі основні завдання дослідження:

- проаналізувати ідіоматичні вирази, порівнявши їх дослівний і самостійний переклади;

- довести, що переклад англійських ідіом не повинен бути дослівним;

• показати творчий підхід до перекладу ідіоматичних виразів для правильної передачі думки з усіма її відтінками;

Інформація про авторів:

Коваль Лариса Миколаївна, ст. викладач, кафедра іноземних мов. Email: larissak751@gmail.com

Чаплик Ольга Андріївна, ст. викладач, кафедра іноземних мов. Email: chaplyk@nltu.edu.ua

Масон Світлана Романівна, ст. викладач, кафедра іноземних мов. Email: mason@nltu.edu.ua

Цитування за ДСтУ: Коваль Л. М., Чаплик О. А., Масон С. Р. Використання ідіом у сучасному англійському діловому дискурсі. Науковий вісник НлтУ України. 2020, т. 30, № 3. С. 122-125.

Citation APA: Koval, L. M., Chaplyk, O. A., \& Mason, S. R. (2020). The use of idioms in modern English business discourse. Scientific Bulletin of UNFU, 30(3), 122-125. https://doi.org/10.36930/40300322 
- висвітлити експресивну функцію та емоційні характеристики англійських бізнес-ідіом;

- обгрунтувати потребу знання та розуміння ідіоматичних виразів та вміння розбиратися у їх тонкощах.

- підкреслити функціональне навантаження та широке використання ідіом на бізнес-форумах, конференціях тощо.

Новизна дослідження полягає в тому, що було вперше встановлено той факт, що ідіоми не пов'язані ні 3 якими обмеженими, конкретними сферами життя в англомовних країнах, а тому необхідно знати не тільки лексичні одиниці і терміни в межах ділового спілкування, але й враховувати національний колорит мови, специфіку бізнес-переговорів.

Практична значущість дослідження полягає в тому, що отримані результати можна використати для подальшого вивчення особливостей бізнес-комунікації, а також застосувати як практичний матеріал для розвитку комунікативної компетенції студентів на заняттях 3 дисципліни "Ділова англійська мова".

Аналіз літературних джсерел. Питання фразеології порушено у фундаментальних працях Ш. Баллі, В. В. Виноградова, А. В. Куніна, І. Р. Гальперіна, О. О. Потебні. Бізнес-фразеологію англійської мови досліджували такі визнані вчені, як: А. Н. Баранова, В. М. Поварова, Т. М. Федулєнкова, В. Д. Берлецька. Проблеми семантики бізнес-фразеології стали об'єктом досліджень у працях сучасних російських вчених - Т. Б. Назарової, Н. Н. Разговорової, І. О. Снєгової та ін. Упродовж останніх десятиліть англійська фразеологія істотно поповнилася працями вітчизняних науковців. Питання класифікації фразеологічних одиниць у своїх дослідженнях висвітлює П. Т. Ерченко. Англійські фразеологізми 3 національно-культурним компонентом - об'єкт уваги Н. Д. Петрової. Питанням бізнес-фразеології приділяє увагу Г. В. Крайчинська. Водночас О. О. Нагорна зосереджує свою увагу на етнокультурних особливостях семантики англійських фразеологізмів.

Матеріали і методи дослідження. Для досягнення поставлених завдань використано такі методи дослідження:

- метод фразеологічного опису, або, як його ще називають, описовий метод, який є основою для подальшого застосування інших методів;

- контекстуальний метод, який дає змогу залучити до сфери фразеології словосполучення, які утворюють постійний контекст - ідіоми;

- семантичний, який аналізує мовні одиниці щодо їх змістово-смислового значення в контексті;

- метод прагматичного аналізу для опису функціонального призначення ідіоматичних одиниць.

\section{Результати дослідження та їх обговорення}

Виділяють такі особливості функціонального навантаження ділової англійської мови: телефонні розмови 3 обговоренням ділових особливостей, ділове листування (кореспонденція), ділові засоби масової інформації, бізнес-зустрічі, техніка бізнес-бесіди, контракти, які спрямовані на бізнес-індустрію $[4,5]$.

Бізнес-англійську, як мову для спеціальних цілей, розглядають з боку взаємозумовленої цілісності усного та писемного мовлення, що вживаються в ділових сферах життя [4, с. 11].

Ділова англійська та загальна англійська мови мають набагато більш спільного, коли йдеться про ідіоми, вирази та фрази. Письмова мова ділового спілкування не є наповненою ідіоматичними виразами, тоді як усне ділове спілкування допускає можливість вживання ідіом не тільки для того, щоб донести необхідну інформацію, але й для створення атмосфери реального спілкування. Правильне використання ідіом занурює співрозмовника в атмосферу англійського життя загалом та бізнесу зокрема, сприяє встановленню більш неформального контакту між партнерами.

Мова ідіом походить від носіїв мови, але для тих, чия рідна мова не англійська, може бути проблематичним знайти правильне слово у потрібний час, можна розгубитися, тому важливо знати коли і як вживати ідіоми [2].

Ідіома - це стійкий, властивий тільки цій мові вираз, що незалежно від значення слів у ньому передає єдине поняття і здебільшого дослівно іншими мовами не перекладається [3]. Це вислів, зрозумілий тільки носіям мови, або тим, хто добре з ним знайомий. Тобто, це сталий вираз, властивий тільки конкретній мові та культуpi, його неможливо дослівно перекласти. Ідіоматичні вирази входять до розділу formulatic language. Дослівний переклад цього поняття "формула спілкування" або "мовленнєвий шаблон". Отже, можна сказати, що formulatic language містить в собі незмінні і неподільні вирази, які $є$ єдиною мовленнєвою одиницею, а не сполученням декількох різних слів. Для того, щоб правильно перекласти ідіоматичний вираз, потрібно повністю відійти від структури речення, його лексичного оформлення, до кінця зрозуміти думку, яка прихована у цьому реченні і виразити ії найбільш грамотно у близькій до оригіналу літературній формі.

В основі багатьох англійських ідіом знаходяться аналогії та метафори. Для того, щоб зрозуміти істинне значення ідіом, їх треба вчити в контексті. Наприклад: коли проект починають, його "get the ball rolling" (дослівно: "змушують шар котитися"), або "get off the ground" (дослівно: "відривають від землі"). Якщо проект відкладають, то його "put on hold" (дослівно: "ставлять на очікування"). Якщо ж проект повністю розпочався і успішно розвивається, то він "in full swing" (дослівно: "на всіх парах"). А якщо проект виявився неуспішним, то його не закривають, a "pull the plug" (дослівно: "висмикують штепсель"). Ідіоматичні вирази дуже часто пов'язані з тією конкретною образністю, яка характерна тільки для англійської мови. Цю образність не завжди вдається зберегти, але пов'язаний з нею зміст передавати потрібно абсолютно точно.

Вивчення мови бізнесу сприяє комплекснішому розумінню англійської мови, оскільки міжмовна комунікація є складним багатоаспектним процесом, що передбачає одночасну взаємодію елементів різного ступеня комунікативної направленості, структурно-семантичної складності та змістовної експлікації комунікативних одиниць [7].

І хоча світ бізнесу має свою власну фразеологію та навіть жаргон, багато ідіом часто вживають бізнесмени як у діловій мові, так і в не бізнесовому середовищі. 3 цієї причини ідіоми не прив'язані до якоїсь обмеженої або специфічної сфери життя або культури в англомовних країнах.

Для того, щоб визначити цілі вживання ідіоматичних сполучень і одиниць в цьому контексті, а також їх 
функціональне навантаження, розглянемо ідіоми "on the grapevine" та "from the horse's mouth".

- I heard on the grapevine that our company is going bankrupt. Is it true?

- Yes, the CEO told me himself. I heard it from the horse's mouth [1, c. 10].

- Ходять чутки, що наша компанія збанкрутує. Чи це правда?

- Так, генеральний директор сказав мені про це. Я чув це з перших вуст.

Цей приклад ілюструє як значення, так і синтаксичні можливості ідіом, які об'єднують в собі лексикологічну, лексикографічну та функціональну сторони мови. Ці ідіоматичні вирази - це розмовний неформальний стиль мови.

Всупереч думці, що мова бізнесу суха, наводимо приклади найчастіше вживаних англійських ідіом, які роблять ділову мову більш живою, виразнішою [6]. Ці вирази насамперед можна почути в діловій сфері, а також вони можуть бути ідеально використані в суспільному житті.

У наведених прикладах ідіоми розташовані згідно 3 їх функціональним навантаженням.

\section{Започаткування бізнесу}

Game plan - a strategy or plan for achieving success (план досягнення успіху). - What is our game plan for dealing with our new competitor?

Get something off the ground/get the ball rolling - to start a project or business (розпочинати проект, бізнес). - We're glad the planning process is over. We'll be looking forward to getting the project off the ground.

Get off to a flying start - to begin an activity very successfully (успішно щось розпочати). - The new marketing compaign got off to a flying start and sales increased.

Learn the ropes - to learn basics of something (вивчати основи чогось). - I'm learning the ropes in my new position.

In a nutshell - to give main facts in a short, clear way (коротко, у декількох словах надавати основні факти). - In a nutshell, this book is about how to motivate employees.

Put someone in the picture - to give the latest information (вводити в курс справи). - A lot happened while you were on holiday. Let me put you in the picture.

Give the thumbs up - to give approval (схвалювати щось). They gave our new proposal the thumbs up.

Give the thumbs down - to deny approval (відмовляти, не схвалювати). - I can't believe she gave us the thumbs down. I thought it was a great idea.

Be on the same page - to share similar opinions and ideas (добре розуміти один одного). - Let's go over the details of what we agreed on to make sure we are on the same page.

\section{Мета та цілі}

A means to an end - way or method of getting to an objective (шляхи досягнення мети) - We use special offers in order to attract bigger orders - in other words, as a means to an end.

Think big - to have ambitious goals and plans for the future (мати амбіційні плани на майбутнє). - I'm not content with just opening one or two more stores. I'm thinking big - I think we can open 10 stores in the next five years.

Make up one's mind - to decide (вирішувати). - I haven't yet made up my mind whether to accept the offer or not.

On purpose - not by accident or chance, but by or with some intention; deliberately (з метою, навмисне). - Although everyone has to be at the meeting on time, the chairman will be a few minutes late, as usual. He does this on purpo$s e$, just to let everyone know who's in charge.
Take action on - to act either in response to circumstances (вживати заходів/діяти у відповідь на обставини). - We need to take firm action now on the reduction in our market share - before matters get worse.

Take steps - to take a series of actions towards a specific objective (здійснювати низку дій щодо досягнення певної мети). - In the course of the next day or so, we shall be taking steps to put our plans into action.

With a view to - with the aim, purpose of (doing) something (з метою зробити щось). - We are opening an office in Budapest with a view to expansion in Eastern Europe.

\section{Зосередження уваги}

Come to the point - to arrive directly at the focus, or the most important part of some activity (переходити до головного). - I'm afraid I can't follow your reasoning; you've been speaking for twenty minutes without coming to the point.

Keep one's eye on the ball - to give something one's full attention and to not lose focus ("стежити за м'ячем", не випускати $з$ виду). - I know we can do it. We just need to keep our eyes on the ball and not lose focus.

Get down to business - to stop making small talks and start talking about serious topics related to business (переходити до справи). - Now, when everyone is here, lets get down to business and talk about proposal.

Get to the bottom of - to find the cause of or the answer to a problem, situation (розуміти суть проблеми, ситуаціï). Staff turnover is on the increase. Management are trying to get to the bottom of the matter.

Zero in on - to identify and concentrate on some target (3oceреджувати увагу на чомусь). - We need to come up with new products and zero in on new markets if we are to stay ahead of our competitors.

\section{Незгода та критика}

At cross purposes - having a difference of opinions, wishes leading to confusion (говорити на "різних мовах", мати протилежну думку, бажання, які ведуть до непорозуміння). - I was thinking of a meeting this week. - I think we're talking at cross purposes.

Get the wrong end of the stick - to not understand something (не розуміти чогось). - If you think our biggest problem is communication then you got the wrong end of the stick $[1, \mathrm{c} .10]$.

Be like talking to a brick wall - to try to communicate with an irresponsible person (все одно, що говорити до стіни). - I've tried to get my supplier to give us a discount several times, but they just won't. It's like talking to a brick wall [1, c.10].

Can't make head nor tail of it - to fail to understand anything (неможливо зрозуміти щось, розібратися в чомусь). This document from our subsidiary makes no sense at all. I can't make head nor tail of it [1, c.10].

Be beside the point - to have no connection with what is being discussed (не мати жодного зв'язку з тим, що обговорюється). - The only important question is whether we go ahead with the project or not; anything else is beside the point.

Shift the blame (or responsibility) (on to) - to try to transfer the weight or focus of blame or responsibility, misdirecting it from where it belongs, in order to avoid it (перекладати відповідальність за щось на когось іншого, "робити когось крайнім"). - He is a bad manager, always shifting the blame for his mistakes on other people.

\section{Кроки до згоди, компромісу}

Be in line with - to be in conformity or agreement with (погоджуватися з кимось, співпрацювати). - Your ideas are very interesting, especially as they're very much in line with our own. 
Be on the same wavelength - to share similar opinions and ideas ("бути на одній хвилі", добре розуміти один одного). - Paola and I agree on most things. We seem to be on the same wavelength.

See eye to eye with somebody - to agree, compromise or cooperate by first appreciating the other's thoughts and needs (мати ідентичні погляди, розуміти з "першого погляду"). - My boss doesn't see eye to eye with me about our marketing campaign.

Go along with - to share the same opinion as; to be in agreement with (поділяти чиїсь думки). - The company is happy to go along with your proposals.

Give and take - to make compromises or an exchange of concessions so that everyone gains or loses to the same extent (піти на компроміс, у якому кожна сторона одержує чи втрачає в однаковій мірі). - All relationships, from marriage to business, call for an element of give and take.

Build bridges - to improve relationships between people who are very different or do not like each other ("наводити мости"; намагатися поліпшити відносини). - A non-governmental organization is engaged in building bridges between different communal groups in the city.

Meet (someone) in half way - to compromise by a reduction in one's own demands, in return for corresponding concession (піти на компроміс, зменшуючи власні вимоги у відповідь на відповідну поступку). - If you're prepared to meet us half way on price, there's a better prospect of a repeat order.

I це тільки невелика кількість прикладів з безлічі яскравих виразів, якими можна збагатити свою англійську мову.

Під час вивчення ділової англійської мови потрібно розуміти, що знання бізнес-лексики не є головною метою навчання. Набагато важливішим є практичне володіння навичками ділового спілкування у різних ситуаціях. Вивчення ідіоматичних виразів під час навчального процесу та їх правильне використання сприяють розвитку та вдосконаленню мовленнєвих навичок майбутніх спеціалістів. Отже, знання ідіоматичних виразів та вміння правильно їх використовувати надають студен- там можливості, які допоможуть їм досягти рівня кваліфікації, необхідного для досягнення успіху у сучасному діловому світі, відчувати себе комфортніше в робочих умовах, де спеціалізована англійська мова є нормою.

\section{Висновки}

За результатами дослідження використання ідіом у сучасному англійському діловому дискурсі можна зробити такі висновки:

- англійські ідіоми набули широкого застосування у розмовному стилі ділової англійської мови;

- для правильного перекладу англійських бізнес-ідіом необхідно враховувати національний колорит мови, культурний менталітет нації;

- експресивна функція є однією з провідних характеристик бізнес-ідіом;

- знання та правильне вживання англійських ідіом надають діловій розмові яскравого характеру, дають змогу співрозмовникам краще розуміти одне одного;

- усі ідіоми, що використовуються в діловій мові, є прагматично навантаженими;

- вивчення ідіом студентами сприяє розвитку їх комунікативної компетенції.

\section{References}

1. Cotton, D., Favley, D., \& Kent, S. (2016). Market Leader. Business English Course. Book. Upper Intermediate. (3rd ed. add. and revised). Longman (Pearson Education), $175 \mathrm{p}$.

2. Goddard, C. (1995). Business Idioms International, Prentice Hall International. $141 \mathrm{p}$.

3. Melnychuk, O. S. (1974). Dictionary of foreign words. Kyiv: URE, 776 p. [In Ukrainian].

4. Nazarova, T. B. (1997). Business English. An Introductory Course for Advanced. Students. Moscow: Dialogue MSU, $138 \mathrm{p}$.

5. Nazarova, T. B., Kuznetsova, J. M., \& Presnoukhina, I. A. (2007). Business English. Vocabulary. A Special Course. Moscow: AST/Astrel, $329 \mathrm{p}$.

6. Oxford Idioms Dictionary for learners of English. (2010). Oxford University. Press, $470 \mathrm{p}$.

7. Vasyliuk, I. M. (2004). Frazeolohizmy yak odynytsi mizhmovnoi komunikatsii. Bulletin of Zhytomyr State University named after Ivan Franko. Pedagogical sciences, 7, 102-105. [In Ukrainian].

L. M. Koval, O. A. Chaplyk, S. R. Mason

Ukrainian National Forestry University, Lviv, Ukraine

\section{THE USE OF IDIOMS IN MODERN ENGLISH BUSINESS DISCOURSE}

The article deals with the proper use of such lexical devices as idioms in the English business language. It considers the theoretical aspect of the notion "idiom" as a persistent indivisible lexical device that conveys a single concept the meaning of which is not determined by the content of its constituent elements. It analyses the communicative and expressive functions of idiomatic expressions and their role in mastering the modern business English by the students whose native language is not English. It pays great attention to the complexity of idioms translation because of their specific ethnic and cultural features. The article highlights the emotionally evaluated and expressive effect of phraseological units during business negotiations. It also emphasizes that many English idioms are based on analogies and metaphors; therefore they should be studied in context in order to understand their meaning correctly. The paper shows that despite the idea that business language is dry, there are a great deal of English idioms that make business language more lively and expressive, and although the business world has its own terminology, many idioms are often used both in the business language and in non-business environment, they can be perfectly used in public life as well. The article provides a range of idioms which can be used on almost any occasion from discussions and meetings to presentations, negotiations, reports, and letters. It gives a definition to each idiom; definitions are followed by example sentences which illustrate both the meanings and syntactical possibilities of the idiom. The article presents some examples of the use of idiomatic expressions according to their functional load (starting a business; purpose and objectives; focusing; disagreement and criticism; steps to compromise and agreement) that helps realize that excellent knowledge of business vocabulary and terms is not enough to feel comfortable in working environment where specialized English is the norm. Much more important is the practical mastery of business communication in different situations, the ability to establish more personal contact between partners, and create an informal, friendly atmosphere of communication. Consequently, the knowledge of idiomatic expressions and the ability to use them correctly provide students with opportunities that will help them achieve the level of qualification required to succeed in today's business world.

Keywords: phraseological units; idiomatic expressions; business communication; definition; syntactic possibilities; level of qualification. 